\title{
Trade Facilitation Effects on International Trade: Evidence From Lower-Middle and Upper-Middle-Income Countries
}

\author{
Alassane D. Yeo ${ }^{1,2}$, Aimin Deng ${ }^{1,2} \&$ Todine Y., Nadiedjoa ${ }^{1}$ \\ ${ }^{1}$ School of Economics and Trade, Hunan University, Changsha, China \\ 2 Institute of Transportation and Logistics, Hunan University, Changsha, China \\ Correspondence: Alassane Dounignatieme Yeo, School of Economics and Trade, Hunan University, Changsha \\ 410082, China. E-mail: yad.elisec@gmail.com
}

Received: April 23, 2020

Accepted: June 28, 2020

Online Published: October 4, 2020

doi:10.5430/ijfr.v11n5p254

URL: https://doi.org/10.5430/ijfr.v11n5p254

\begin{abstract}
This paper presents an empirical analysis of the impact of trade facilitation on international trade, as well as the effects of two dimensions: hard and soft infrastructure. Using 18 primary variables, we constructed four indicators of 30 lower-middle-income and 33 upper-middle-income countries over the period 2011-2017. After applying the system-generalised method of moments (GMM), the main finding is that all trade facilitation indicators have a significant effect on exports. However, improvements in physical infrastructure are more likely to increase exports than the efficiency of borders, transport, information and communication technologies (ICTs) and institutions, from the most significant to the least significant. It is also found that the effect of hard infrastructure on exports is virtually the same as that of soft infrastructure. Hard and soft infrastructure must therefore be considered at the same level, as the effectiveness of international trade depends on both.
\end{abstract}

Keywords: trade facilitation, hard and soft infrastructure, system-generalised method of moments, exports

\section{Introduction}

Trade facilitation is increasingly important in national and international trade policies. In recent decades, it has become an essential instrument for the effective international trade and economic development of countries, due to its impact on competitiveness and its growing capacity to attract foreign direct investment, particularly in the area of infrastructure. Trade facilitation has therefore emerged as a crucial challenge for the world trading system to such an extent that many international organizations have focused on this subject. The United Nations Conference on Trade and Development (UNCTAD) focuses on transport infrastructure and assists developing countries in identifying their needs and priorities regarding trade and transport facilitation. The UNCTAD also provides assistance in planning the implementation of specific trade facilitation measures. At the same time, the Organisation for Economic Co-operation and Development (OECD) focuses on trade facilitation in developed countries. It is a set of measures that simplify and rationalize the technical and legal procedures of products entering or leaving a country for international distribution. In a broader sense, trade facilitation covers the whole range of border procedures, from the electronic exchange of data in a transfer to the simplification and harmonisation of trade documents, as well as the possibility of appealing against administrative decisions of border services.

Moreover, there is no exact and standard definition of trade facilitation, however, all existing approaches are moving towards the same ideas of transparency, simplification, modernisation, and harmonisation. Trade facilitation, therefore, is the simplification and harmonisation of trade procedures through reduced transport costs (APEC, 1999; UNCTAD, 2001; Fink, Mattoo \& Neagu, 2002); improved port facilities (Fink, Mattoo \& Neagu, 2002); efficient and modern customs regimes (Hummels, 2001); transparent and harmonised regulations (Hertel, Walmsley \& Itakura, 2001); and improved information technology infrastructure (Freund \& Weinhold, 2000). For instance, the World Trade Organisation (WTO) has traditionally used a narrow definition, saying that trade facilitation is "the simplification, modernisation, and harmonisation of international export and import procedures.

Trade Facilitation is a whole range of measures aimed at reducing the complexity and cost of the trade transaction process and ensuring that all these activities are carried out in an efficient, transparent and predictable manner. Wilson, Mann and Otsuki (2005) go further by adding a broader range of measures such as infrastructure, 
institutional transparency and good governance, and domestic regulations. All of these factors can impact trade performance through the cost channel. However, instead of focusing exclusively on "on-the-border" factors, such as the simplicity of export and import procedures, or other "behind-the-border" factors, such as transparency and an improved business environment, other factors have also been identified as important for facilitating trade. In addition, ICT, infrastructure and services are becoming increasingly essential trade facilitators due to the rapid integration of networked information technologies into almost every aspect of the international supply chain.

This study follows that proposed by Portugal-Perez and Wilson (2012), which widely defined trade facilitation as any policy measure aimed at diminishing trade costs. Trade facilitation measures can be considered along two dimensions: investment in "hard" infrastructure (highways, railroads, ports, etc.) and "soft" infrastructure (transparency, customs efficiency, institutional reforms, etc). This paper aims to provide an empirical analysis of the impact of trade facilitation on international trade, as well as the impact of these two dimensions: hard and soft infrastructure. Our database included countries with different levels of development, such as a lack of infrastructure, poor governance and lengthy procedures in some, and high tariffs and high trade costs in others. Therefore, we are looking for evidence that trade facilitation is essential in bilateral trade.

Therefore, our analysis first requires that we define and construct a trade facilitation index using a number of primary variables: quality of air, ports, railroads and roads, availability of latest technologies, business ICT use, mobile telephone subscriptions/100 pop, firm-level technology absorption, individuals using the internet, cost to export, time to export, document to export, government efficiency, burden of customs procedures, burden of government regulation, irregular payments and bribes, prevalence of trade barriers and transparency of government policymaking. Then, the system-GMM is used to deal with endogeneity issues in panel data. This study hopes to contribute to the literature on the importance of improving trade facilitation in lower-middle and upper-middle-income countries, as well in Sub-Saharan Africa and East Asia Pacific.

The paper is structured as follows: the next section provides an overview of the recent empirical literature on trade facilitation measures, and its impact on international trade. Section 3 describes the methodology, data, and how trade facilitation variables have been constructed in the study. Section 4 reports the empirical findings. Finally, section 5 concludes.

\section{Literature Review}

The improvement of trade facilitation has become central to trade policy and has attracted the attention of many researchers in recent years. A large number of studies have shown the evidence that improving transport efficiency and business environment, reducing barriers to trade, promoting regional integration (Wilson, Mann, \& Otsuki, 2003; Portugal-Perez \& Wilson, 2012); improving trade policy, the simplification and harmonization of documents, the streamlining of procedures and the use of automated processes (Moïsé \& Sorescu, 2013) are all considered necessary to enhance the efficiency of trade. The significant reduction in trade costs, in particular export and import delays, have led to a significant increase in the volume of trade as well as direct gains from trade policy reform.

In general, the speeding up of administrative procedures is recognized as a major factor in reducing the costs and time needed for the distribution of goods. Several studies employ aggregate estimates of cost and time in trade to estimate the effects of reducing delays in cross-border trade (Minor \& Tsigas,2008; Clark, Dollar, \& Micco,2004). Shepherd and Wilson (2008) analysed trade facilitation in ASEAN member countries and found that import and export costs vary considerably across member countries, ranging from very low to moderately high. However, these changes in transport costs affect both exports and imports. Djankov, Freund and Pham (2010) used a modified gravity equation and newly-collected World Bank data on the days it takes to move standard cargo from the factory gate to the ship in 126 countries, to determine how time delays affect international trade. The results showed that, on average, each additional day of delay before a product is shipped reduces trade by at least $1 \%$. Delays have an even greater impact on developing countries' exports and mainly on exports of time-sensitive goods, such as perishable agricultural products. In particular, one day's delay reduces a country's relative exports of time-sensitive agricultural products by 6 per cent compared to those of non-time-sensitive agricultural products.

The current theoretical debate on trade facilitation concerning developing countries highlights the impact of infrastructure quality on international trade as well as the impact of physical and non-physical infrastructures. Shepherd (2016) examined the connections between trade facilitation and infrastructure on the one hand, and value chain participation, on the other. Using data for 189 countries, including 44 in sub-Saharan Africa, it was found a statistically significant association between exports and indicators of infrastructure development and trade facilitation performance. Improving regional trade facilitation infrastructure in Sub-Saharan Africa are likely to lead to growth and poverty reduction, through both direct and indirect channels. However, there may be specific negative 
effects on particular groups in the absence of complementary policies (Jouanjean, Gachassin, \& te Velde, 2016). Furthermore, a Shepherd and Wilson (2008) study on trade facilitation in ASEAN member countries point out the vital role that transport infrastructure can play in enhancing intra-regional trade. By applying a standard gravity model, the authors find that trade flows in Southeast Asia are particularly sensitive to transport infrastructure and information and communications technology.

Although studies have shown that reducing trade barriers increases the volume of trade between countries (French, 2016; Kovak, 2013), Iwanow and Kirkpatrick (2009) have presented a different picture earlier. They elaborate a standard gravity model augmented with trade facilitation, regulatory quality and infrastructure indicators to measure the impact of trade facilitation and other trade-related institutional constraints on the performance of manufactured exports, particularly in Africa. In most developing countries, corruption and poor-quality institutions result in non-compliance with trade regulations and policies, thus damaging as much business as the country's economy in general. Anderson and Marcouiller (2002) suggest that the growth of international trade can be increased if countries follow a common set of import and export rules, regulations and standards. Helble, Shepherd and Wilson (2009) showed that increasing the transparency of the trading environment can be an important complement to traditional liberalization of tariff and non-tariff barriers. However, they suggested that improving trade-related transparency in APEC could have significant benefits by raising intra-APEC trade by approximately US $\$ 148$ billion or 7.5 per cent of baseline trade in the region. Therefore, a country's trade is dependent not only on its trade facilitation reforms but also on those of the trading partners (Jordaan, 2014). The improvement of the customs environment in the importing country brings the largest gain in terms of increased trade flows, followed by the regulatory environment and national infrastructure.

Estimates in the existing literature suggest that the benefits of trade facilitation are significant. Sub-Saharan Africa has been shown on a comparative basis to lag behind other regions in providing investment and a business environment favourable to private sector development (Eifert, Gelb, \& Ramachandran, 2005). In the context of trade performance, it is argued that lower-middle-income countries can be characterized as a high cost and high-risk environment that constrains private sector investment and tradable production (Collier \& Gunning, 1997). This constraint is particularly severe in the manufacturing sector and has been found to be responsible for reducing Africa's international competitiveness and hampering the diversification of manufactured exports (Elbadawi, Mengistae, \& Zeufack, 2006). Regarding upper-middle-income countries as well as the Asia-Pacific region, the global gains from improved trade facilitation ( $\$ 110$ billion) are comparable in magnitude to the results of full liberalization of trade in goods and services (\$150 billion) (Wilson et al., 2002).

\section{Methodology}

\subsection{Model Specification}

The first objective of this study is to examine the effects of trade facilitation on exports in selected economies in the lower-middle and upper-middle-income countries. Based on these theoretical considerations, we specify our empirical model, which relates export to trade facilitation and other explanatory variables as follows:

$$
X_{i t}=\phi+\alpha X_{i t-1}+\beta T F_{i t}+\delta W_{i t}+\mu_{i}+\gamma_{t}+\varepsilon_{i t}
$$

for $\mathrm{i}=1 ; 2 ; . . ; \mathrm{N}$ and $\mathrm{t}=1 ; 2 ; \ldots ; \mathrm{T}$

Where $X_{i t}$ is a measure of total exports for country i at time $\mathrm{t}$; $T F_{i t}$ is a measure of trade facilitation (i.e., physical

infrastructure, ICT, border and transport efficiency, and institution) for country i at time t; $W_{i t}$ is a set of

(exogenous); $\mu_{i}$ and $\gamma_{t}$ are respectively country-specific and time-specific fixed effects, and $\varepsilon_{i t}$ are idiosyncratic

disturbances; $\phi, \alpha, \beta$, and $\delta$ are estimable parameters. The dependent variable (total export) is used as a proxy

for international trade. A standard set of control variables, including population density, was measured by people per 
sq. km of lands and was expected to have a positive effect on exports (Morrison, 1977) and macroeconomic conditions captured by the population and GDP per capita.

With evidence that exports from high-income countries are significantly high, GDP per capita was included in the model to test whether it has an impact on exports. "Year dummies" was added to our dataset in order to capture the effect of time-series trends. However, time series data is not generally a meaningful source of causal inference because of the lack of compelling counterfactual variables. Additional variables such as East Asia Pacific and Sub-Saharan Africa dummies were included in order to indicate the absence or presence of certain effects that may be expected to shift the outcome. The indicator variables with values of 1 or 0 describe whether the region is East Asia Pacific or not and whether the region is Sub-Saharan Africa or not.

This study also estimated the impact of both hard and soft infrastructure measures on exports. The following model was applied:

$$
\begin{array}{r}
X_{i t}=\phi+\alpha X_{i t-1}+\beta H I_{i t}+\delta W_{i t}+\mu_{i}+\gamma_{t}+\varepsilon_{i t} \\
X_{i t}=\phi+\alpha X_{i t-1}+\beta \mathrm{SI}_{\mathrm{it}}+\delta \mathrm{W}_{\mathrm{it}}+\mu_{\mathrm{i}}+\gamma_{\mathrm{t}}+\varepsilon_{\mathrm{it}}
\end{array}
$$

Where HI was hard infrastructure, and SI was soft infrastructure. The dependent and other independent variables were the same as in equation (1). A proliferation of instruments may overfit endogenous variables and lead to a loss of power but, following relevant literature, the Arellano and Bover (1995), and Blundell and Bond (1998) system-GMM estimation can easily restrict the maximum lag length of the lagged instruments. The conventional system GMM estimator uses instruments for the first-differenced version of equation (1), which removes the time-invariant variables and instruments for the level version of the model from which the time-invariant variables are not removed:

$$
\Delta X_{i t}=\phi+\alpha \Delta X_{i t-1}+\beta \Delta T F_{i t}+\delta \Delta W_{i t}+\Delta \varepsilon_{i t}
$$

Using panel data, system GMM provides an asymptotically efficient inference assuming a minimal set of statistical assumptions and presents much better finite sample properties in terms of bias and root mean squared error than that of the difference GMM estimator (Blundell \& Bond, 1998) and (Blundell, Bond, \& Windmeijer, 2001). However, Bun and Windmeijer (2010) show that there is also a weak instrument problem for the equation in levels. In addition, the first lag of total export is included to capture the initial levels of trade facilitation as well as its persistence over time. To facilitate interpretation of the parameters as elasticities, all variables have been log transformed where necessary.

\subsection{Data}

The database for this study covers 63 countries, including 30 lower-middle-income countries and 33 upper-middle-income countries from 2011 to 2017. This study, based on trade facilitation measures, first collected 18 variables from several primary sources such as WEF's Global Competitiveness Report and the Doing Business report. Secondly, the indicators are re-scaled on a range of 0 (lowest performer) to 1 (top performer) using the min-max normalisation method. The data for total export, population density and the GDP per capita was obtained from world development indicators (WDI). Table 1 presents the data sources, and how trade facilitation measures are constructed and summary statistics are displayed in Table 2 . 
Table 1. Description of variables and data sources

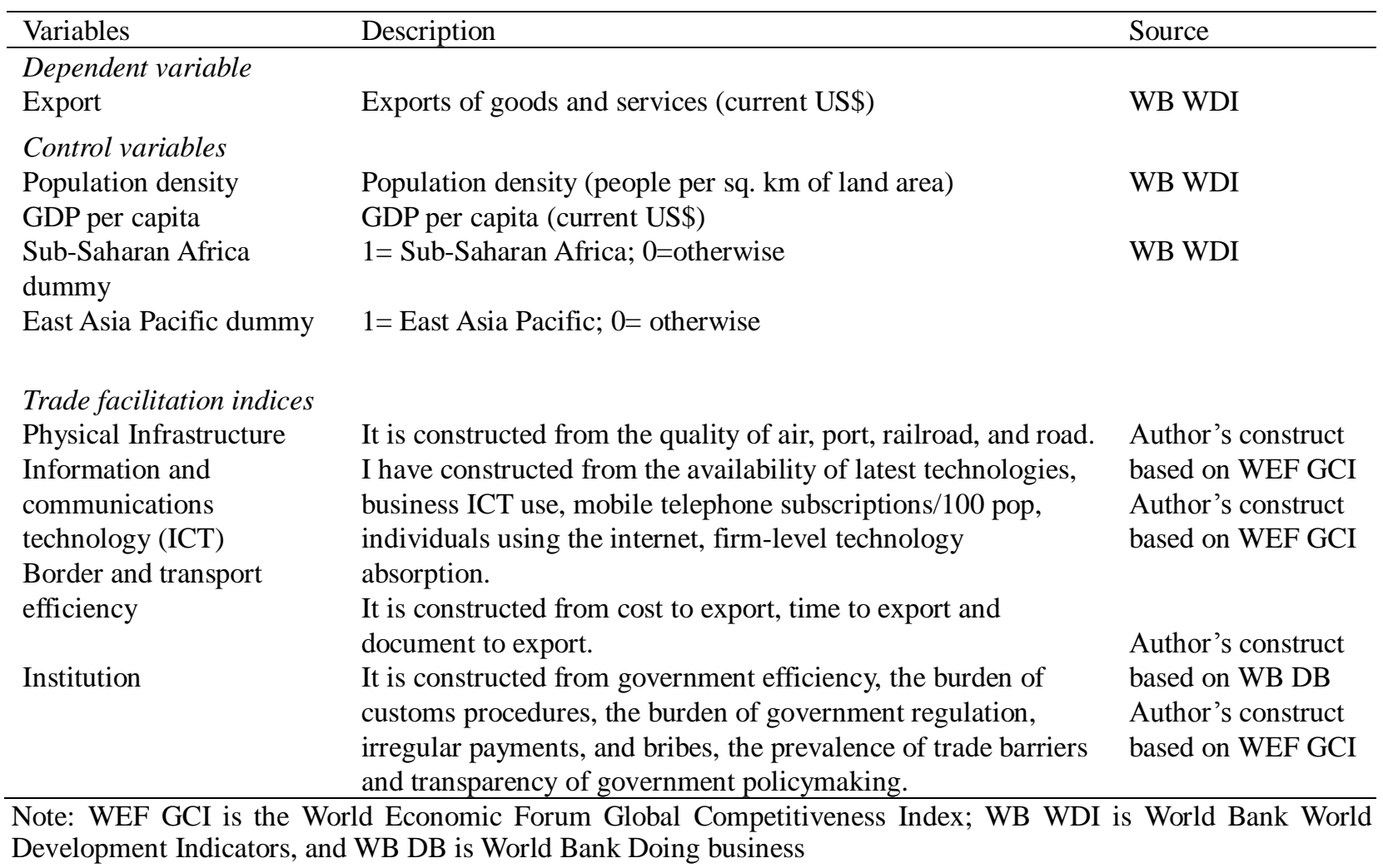

Development Indicators, and WB DB is World Bank Doing business

Table 2. Summary statistic

\begin{tabular}{|c|c|c|c|c|c|}
\hline Variable & Obs., $\mathrm{N}$ & Mean & Std. Dev. & Min & Max \\
\hline Exports & 436 & $1.03 e+11$ & $3.00 \mathrm{e}+11$ & $5.97 e+07$ & $2.46 \mathrm{e}+12$ \\
\hline GDP per capita & 438 & 4963.89 & 3259.259 & 835.7893 & 16007.09 \\
\hline Population Density & 441 & 130.8626 & 186.8379 & 1.777541 & 1265.036 \\
\hline Quality of air & 441 & .603271 & .179302 & 0 & 1 \\
\hline Quality of port & 441 & .5382575 & .1989257 & 0 & 1 \\
\hline Quality of railroad & 434 & .3871128 & .243025 & -.0154912 & 1 \\
\hline Quality of road & 441 & .4745558 & .1983498 & 0 & 1 \\
\hline Availability of latest technologies & 441 & 6479538 & .164993 & 0 & 1 \\
\hline Business ICT use & 441 & .3006509 & .206621 & 0 & 1 \\
\hline Mobile telephone subscription/100 pop & 441 & .5254427 & .1757938 & $2.07 \mathrm{e}-07$ & 1 \\
\hline Individuals using internet & 441 & .4104038 & .2380897 & 0 & 1 \\
\hline Firm-level technology absorption & 441 & 6706061 & .1620706 & 0 & 1 \\
\hline Cost to export & 441 & .1399339 & .1426944 & -.4165039 & 1 \\
\hline Time to export & 441 & 1939738 & .1789243 & -.4383562 & 1 \\
\hline Document to export & 441 & .3773891 & .2960307 & -1.714286 & 1 \\
\hline Government efficiency & 441 & .5335842 & .1502705 & $5.19 \mathrm{e}-11$ & 1 \\
\hline Burden of customs procedures & 441 & .5588429 & .1625238 & -.1483275 & 1 \\
\hline Burden of government regulation & 441 & .5588429 & .1625238 & -.1483275 & 1 \\
\hline Irregular payments and bribes & 441 & .4445837 & .1885965 & $-5.08 \mathrm{e}-11$ & 1 \\
\hline Prevalence of trade barriers & 441 & .6158103 & .1785285 & -.5338375 & 1 \\
\hline $\begin{array}{l}\text { Transparency of government } \\
\text { policymaking }\end{array}$ & 441 & .62038 & .1534873 & $-8.86 \mathrm{e}-11$ & 1 \\
\hline
\end{tabular}




\subsection{Construction of Trade Facilitation Measures}

We constructed trade facilitation measures according to two dimensions: hard infrastructure (physical infrastructure and ICT) and soft infrastructure (border and transport efficiency, and institution).

Physical infrastructure consists of a wide range of systems and facilities that house and transport people and goods, and provide services. Four indicators, quality of ports, airports, roads, and railroads, were used to measure the level of development and the quality of infrastructure.

Information and communication technology (ICT) plays an increasingly important role in modern economics, among other things as an instrument in development cooperation, in driving innovation and efficiency in many areas, and in improving productivity and reducing transaction costs. It is constructed as the simple average of five primary indicators (availability of latest technologies, business ICT use, mobile telephone subscriptions/100 pop, individuals using the internet, and firm-level technology absorption).

Border and transport efficiency. Lower trade costs and increased transport efficiency across countries are the mains reasons why border and transport efficiency are so important for trade. It aims to quantify the level of efficiency of customs and domestic transport that is reflected in the time, cost and number of documents necessary for export and import procedures. The measures used in our study are constructed based only on export procedures.

Institution refers to the quality of contract enforcement, property rights, shareholder protection, and the like, which are an important determinant of trade flows (Do \&Levchenko, 2006). The indicators used to represent institutional quality are government efficiency, the burden of customs procedures, the burden of government regulation, irregular payments and bribes, the prevalence of trade barriers and transparency of government policymaking.

Table 3. Measurement model.

\begin{tabular}{llll}
\hline Trade facilitation index & Primary variable & $\begin{array}{l}\text { Composite } \\
\text { reliability }\end{array}$ & Factor loading \\
\hline Physical Infrastructure & Quality of air & 0.809 & 0.920 \\
& Quality port & & 0.928 \\
& Quality railroad & & 0.784 \\
& Quality road & 0.777 & 0.870 \\
Information and & Availability of latest technologies & & 0.930 \\
communications & Business ICT use & & 0.877 \\
technology (ICT) & Mobile telephone subscriptions/100 pop & 0.734 \\
& Firm-level technology absorption & & 0.867 \\
Border and & Individuals using internet & 0.541 & 0.862 \\
efficiency & Cost to export & & 0.887 \\
Institution & Time to export & 0.647 & 0.901 \\
& Document to export & & 0.624 \\
& Government efficiency & 0.937 \\
& Burden of customs procedures & 0.811 \\
& Burden of government regulation & & 0.777 \\
& Irregular payments and bribes & & 0.764 \\
& Prevalence of trade barriers & & 0.726 \\
& Transparency of government policymaking & & 0.861 \\
\hline
\end{tabular}

\section{Empirical Results and Discussions}

The measurement model, as presented in table 3 , shows that the factor loads of all primary variables are greater than 0.7, as expected (Hair et al., 1998), and meets the required reliability and validity criteria. The reliability of the trade facilitation index (physical infrastructure, ICT, border and transport efficiency and institutions) was measured by composite reliability, and the measures of $0.809,0.777,0.541$ and 0.647 , respectively, demonstrate once again the high reliability of the results. This result allows us to validate our measures of physical infrastructure, ICT, border 
and transportation efficiency and institution through factor analysis, in which the values of the saturation coefficient were at a high level and above the 0.5 thresholds, indicating the significant level of the saturation coefficient and the explicit composition of the factors (Werts, Linn, \& Jöreskog, 1974).

This section reports the results of applying the GMM estimator method described in Section 3. The explanatory variable and the error term are correlated in the model. As we expected, the output presents strong evidence against the null hypothesis of zero autocorrelation in the first-differenced errors in order 1. The value of the test for second-order autocorrelation matches those reported in Arellano and Bond (1991) and presents no evidence of model misspecification. P-values for the difference in the Hansen test of the system GMM instruments reveal the validity of level instruments. Table 4 presents the system-GMM regression of trade facilitation index on exports and Tables 5-6 show the system-GMM regression of hard and soft infrastructure measures on exports. In each table, the control explanatory remains the same. We also add East Asia Pacific and Sub-Saharan Africa dummies to existing year dummies variables.

\subsection{Effects of Trade Facilitation on Exports}

Four indicators were regressed (physical infrastructure, ICT, border and transport efficiency and institution) in Table 4, and presented in the Models 1-4. All indicators were regressed in model 5. The results show the significant impact of trade facilitation indices on exports. All variables are statistically significantly related to export at $1 \%$ except for the physical infrastructure in Column 1, which is significant at $10 \%$. We found a positive relationship between the physical infrastructure and exports, and a negative relationship between the institution and exports. The results reveal that both ICT and border and transport efficiency play a significant role in exports. For instance, a $1 \%$ increase in the border procedure can decrease exports by 0.24 and 0.19 percentage points in Columns 3 and 5, respectively. The increase in the use of ICT can also reduce exports by 1.08\% and 1.07\% in Model 3 and Model 5, respectively. This result is not in line with those obtained by Shepherd and Wilson (2008); Li and Wilson (2009), who found a statistically significant and positive relationship between ICT and trade.

Many lower-middle-income countries remain underdeveloped in terms of ICT, however, and therefore, the negative coefficient of the full model for Sub-Saharan Africa dummies, which is equal to -0.163 , reveals that even after accounting for the effects of all the explanatory variables in the model (including physical infrastructure, ICT, border and transport efficiency, and institution), Sub-Saharan Africa countries earn on average 0.163 less per year than non-Sub-Saharan Africa countries. The coefficient of East Asia Pacific dummies, which is 1.75, also shows that accounting for the impact of all the variables, countries in East Asia Pacific earn on average 1.75 more per year than others.

The result of the full model shows that the coefficient for GDP per capita is positive and statistically significant. This suggests that a bigger market size implies higher trade flows of economies (Ismail \& Mahyideen, 2015). Column 1 shows the negative and significant effect of GDP per capita on exports, which makes it difficult to determine whether GDP per capita affects exports negatively or positively. The coefficient for population density is negative and insignificant in most models, as shown by Columns 1, 2, 4, 5. This confirms the results of previous studies, according to which an increasing population without correspondingly increase resources (e.g., land, infrastructure, and social amenities among others) puts pressure on existing scarce resources, which tends to lower the quality of life, thus lowering a country's total exports (Sakyi, Bonuedi,\& Opoku, 2018).

Table 4. System-GMM estimates of the effect of trade facilitation on export

\begin{tabular}{llllll}
\hline Variables & Model 1 & Model 2 & Model 3 & Model 4 & Model 5 \\
\hline & $0.878^{* * *}$ & $0.745^{* * *}$ & $0.792^{* * *}$ & $0.771^{* * *}$ & $0.633 * * *$ \\
Export (-1) & $(0.0153)$ & $(0.0159)$ & $(0.0152)$ & $(0.0123)$ & $(0.0297)$ \\
& $-0.259^{* * *}$ & $0.798^{* * *}$ & 0.024 & $0.117 * * *$ & $0.802 * * *$ \\
GDP per capita & $(0.0481)$ & $(0.0423)$ & $(0.0202)$ & $(0.0381)$ & $(0.0953)$ \\
& -0.0407 & -0.0555 & $0.201 * * *$ & -0.0491 & -0.0175 \\
Population density & $(0.0623)$ & $(0.043)$ & $(0.05)$ & $(0.0301)$ & $(0.116)$ \\
physical & $0.130^{*}$ & & & & $0.540^{* * *}$ \\
infrastructure & $(0.073)$ & & & & $(0.193)$ \\
& & $-1.084 * * *$ & & $-1.069^{* * *}$ \\
ICT & & $(0.0437)$ & & & $(0.069)$
\end{tabular}




\begin{tabular}{|c|c|c|c|c|c|}
\hline \multicolumn{3}{|l|}{$\begin{array}{l}\text { Border and transport } \\
\text { efficiency }\end{array}$} & \multicolumn{2}{|l|}{$\begin{array}{l}-0.243 * * * \\
(0.0152)\end{array}$} & $\begin{array}{l}-0.194 * * * \\
(0.0693)\end{array}$ \\
\hline Institution & & & & $\begin{array}{l}-0.371 * * * \\
(0.0891)\end{array}$ & $\begin{array}{l}-0.276 \\
(0.217)\end{array}$ \\
\hline Sub-Saharan Africa & $\begin{array}{l}-0.832 * * * \\
(0.0774)\end{array}$ & $\begin{array}{l}0.182 * \\
(0.0939)\end{array}$ & $\begin{array}{l}0.514 * * * \\
(0.093)\end{array}$ & $\begin{array}{l}0.139 \\
(0.119)\end{array}$ & $\begin{array}{l}0.164 \\
(0.147)\end{array}$ \\
\hline East Asia Pacific & $\begin{array}{l}0.929 * * * \\
(0.324)\end{array}$ & $\begin{array}{l}1.609 * * * \\
(0.288)\end{array}$ & $\begin{array}{l}-1.186^{* * * *} \\
(0.28)\end{array}$ & $\begin{array}{l}1.663 * * * \\
(0.474)\end{array}$ & $\begin{array}{l}1.750 * * * \\
(0.557)\end{array}$ \\
\hline Constant & $\begin{array}{l}5.382 * * * \\
(0.791)\end{array}$ & $\begin{array}{l}-1.361 * * \\
(0.604)\end{array}$ & $\begin{array}{l}4.277 \\
(86.57)\end{array}$ & $\begin{array}{l}4.043 * * * \\
(0.444)\end{array}$ & $\begin{array}{l}1.725 \\
(1.736)\end{array}$ \\
\hline Years dummies & yes & yes & yes & yes & yes \\
\hline No. of. observations & 367 & 367 & 367 & 367 & 367 \\
\hline No. of. countries & 63 & 63 & 63 & 63 & 63 \\
\hline $\mathrm{AR}(2)$ & -1.33 & -1.03 & -1.62 & -1.07 & -0.47 \\
\hline AR (2) p-value & 0.182 & 0.303 & 0.106 & 0.284 & 0.642 \\
\hline Hansen Stat & 12.16 & 5.59 & 10.48 & 3.26 & 11.79 \\
\hline Hansen p-value & 0.352 & 0.899 & 0.487 & 0.987 & 0.380 \\
\hline
\end{tabular}

Source: Authors' calculations based on data obtained from the World Bank's data and data constructed from quality of air, port, railroad and road, availability of latest technologies, business ICT use, mobile telephone subscriptions/100 pop, individuals using internet, firm-level technology absorption, cost to export, time to export, document to export, government efficiency, burden of customs procedures, burden of government regulation, irregular payments and bribes, prevalence of trade barriers and transparency of government policymaking. Robust standard errors in parentheses.

$* * * \mathrm{p}<0.01, * * \mathrm{p}<0.05, * \mathrm{p}<0.1$

\subsection{Effects of Hard Infrastructure on Exports}

This section discusses the results of the impact of hard infrastructure on exports. The number of estimations was regressed to apply to hard infrastructure variables and presented in Table 5. Among the nine indicators, only three were positive and significant at $1 \%$; the other six were negative and significant. Columns 1-4 report the results of physical infrastructure. Quality of port, railroad and road have a positive relationship with exports. An improvement in the quality of the port, railroad and road by $1 \%$ increases exports by $0.07 \%, 0.049 \%$, and $0.13 \%$ respectively. Columns 5-9 show the impact of ICT on exports. As a result, the coefficient for all ICT variables is negative and statistically significant for the estimations of exports, as in Table 4.

In Column 10, a $10 \%$ increase of Sub-Saharan Africa hard infrastructure will increase total exports by 0.4 percentage points, and a $1 \%$ increase in East Asia Pacific hard infrastructure will increase total exports by 1.98 percentage points. The coefficient of the dummy variable for East Asia Pacific was significant and positive for all hard infrastructure variables for the entire period. This indicates that hard infrastructure in East Asia Pacific plays a vital role in exports compared to other lower and upper-middle countries.

Table 5. System-GMM estimates of the effect of hard infrastructure on export.

\begin{tabular}{ccccccccccc}
\hline Variables & Model 1 & Model 2 & Model 3 & Model 4 & Model 5 & Model 6 & Model 7 & Model 8 & Model 9 & Model 10 \\
\hline & $0.843^{* * *}$ & $0.883^{* * *}$ & $0.861^{* * *}$ & $0.862^{* * *}$ & $0.786^{* * *}$ & $0.832^{* * *}$ & $0.859^{* * *}$ & $0.908^{* * *}$ & $0.794^{* * *}$ & $0.791^{* * *}$ \\
Export (-1) & $(0.0171)$ & $(0.0142)$ & $(0.0137)$ & $(0.011)$ & $(0.0112)$ & $(0.0144)$ & $(0.00896)$ & $(0.0174)$ & $(0.0111)$ & $(0.0402)$ \\
& $0.160^{* * *}$ & $-0.135^{* * *}$ & $-0.0476^{* * *}$ & 0.00456 & $0.416^{* * *}$ & $0.243^{* * *}$ & $0.160^{* * *}$ & $0.100^{* * *}$ & $0.337^{* * *}$ & $-0.361^{* * *}$ \\
GDP per Capita & $(0.0263)$ & $(0.0222)$ & $(0.0174)$ & $(0.0201)$ & $(0.0313)$ & $(0.0243)$ & $(0.0159)$ & $(0.0344)$ & $(0.0161)$ & $(0.0808)$ \\
Population & $0.247^{* * *}$ & $0.102^{* * *}$ & $0.163^{* * *}$ & $0.165^{* * *}$ & $0.248^{* * *}$ & 0.0343 & $0.0565^{* * *}$ & $0.110^{* * *}$ & $0.274 * * *$ & 0.0522 \\
density & $(0.0287)$ & $(0.0254)$ & $(0.0225)$ & $(0.0275)$ & $(0.0281)$ & $(0.0238)$ & $(0.0184)$ & $(0.0229)$ & $(0.0176)$ & $(0.0998)$ \\
& $-0.477^{* * *}$ & & & & & & & & & -0.0271 \\
Quality of air & $(0.0245)$ & & & & & & & & & $(0.196)$ \\
& & $0.0725^{* * *}$ & & & & & & & & $0.191^{* *}$ \\
Quality of port & $(0.0141)$ & & & & & & & & $(0.0833)$ \\
\hline
\end{tabular}




\begin{tabular}{|c|c|c|c|c|c|c|c|c|c|c|}
\hline $\begin{array}{l}\text { Quality of } \\
\text { railroad }\end{array}$ & & & $\begin{array}{c}0.0492 * * * \\
(0.0107)\end{array}$ & & & & & & & $\begin{array}{l}-0.0504 \\
(0.0609)\end{array}$ \\
\hline Quality of road & & & & $\begin{array}{l}0.113 * * * \\
(0.0235)\end{array}$ & & & & & & $\begin{array}{l}-0.0791 \\
(0.123)\end{array}$ \\
\hline $\begin{array}{l}\text { Availability of } \\
\text { latest } \\
\text { technologies }\end{array}$ & & & & & $\begin{array}{l}-0.69 * * * \\
(0.0219)\end{array}$ & & & & & $\begin{array}{l}0.682 * * \\
(0.317)\end{array}$ \\
\hline Business ICT use & & & & & & $\begin{array}{l}-0.260 * * * \\
(0.00899)\end{array}$ & & & & $\begin{array}{l}0.281 * * * \\
(0.0823)\end{array}$ \\
\hline $\begin{array}{l}\text { Mobile telephone } \\
\text { subscriptions }\end{array}$ & & & & & & & $\begin{array}{l}-0.455 * * * \\
(-0.0042)\end{array}$ & & & $\begin{array}{c}-0.682 * * * \\
(0.0491)\end{array}$ \\
\hline $\begin{array}{l}\text { Firm-level } \\
\text { technology } \\
\text { absorption }\end{array}$ & & & & & & & & $\begin{array}{l}-0.247 * * * \\
(0.00941)\end{array}$ & & $\begin{array}{c}0.379 * * * \\
(0.0782)\end{array}$ \\
\hline $\begin{array}{l}\text { Individuals using } \\
\text { internet }\end{array}$ & & & & & & & & & $\begin{array}{c}-0.715 * * * \\
(0.0172)\end{array}$ & $\begin{array}{c}-1.140 * * * \\
(0.419)\end{array}$ \\
\hline $\begin{array}{c}\text { Sub-Saharan } \\
\text { Africa }\end{array}$ & $\begin{array}{c}0.0501 \\
(0.0745)\end{array}$ & $\begin{array}{c}-0.527 * * * \\
(0.0571)\end{array}$ & $\begin{array}{c}-0.372 * * * \\
(0.0601)\end{array}$ & $\begin{array}{c}-0.216^{* * * *} \\
(0.0539)\end{array}$ & $\begin{array}{l}0.554 * * * \\
(0.103)\end{array}$ & $\begin{array}{l}-0.556 * * * \\
(0.0717)\end{array}$ & $\begin{array}{c}-0.190 * * * \\
(0.0333)\end{array}$ & $\begin{array}{c}-0.689 * * * \\
(0.0814)\end{array}$ & $\begin{array}{l}0.440 * * * \\
(0.073)\end{array}$ & $\begin{array}{l}0.403 * \\
(0.203)\end{array}$ \\
\hline East Asia Pacific & $\begin{array}{c}0.833 * * * \\
(0.0948)\end{array}$ & $\begin{array}{c}0.489 * * * \\
(0.14)\end{array}$ & $\begin{array}{c}0.560 * * * \\
(0.111)\end{array}$ & $\begin{array}{c}0.702 * * * \\
(0.125)\end{array}$ & $\begin{array}{c}1.130 * * * \\
(0.129)\end{array}$ & $\begin{array}{c}0.860 * * * \\
(0.146)\end{array}$ & $\begin{array}{c}0.946^{* * * *} \\
(0.149)\end{array}$ & $\begin{array}{c}0.179 * \\
(0.0955)\end{array}$ & $\begin{array}{c}1.335^{* * * *} \\
(0.16)\end{array}$ & $\begin{array}{c}1.987 * * * \\
(-0.5790\end{array}$ \\
\hline Constant & $\begin{array}{c}1.084 \\
(42.09)\end{array}$ & $\begin{array}{c}3.598 \\
(166.7)\end{array}$ & $\begin{array}{c}3.103 \\
(101.8)\end{array}$ & $\begin{array}{l}2.431 \\
(151)\end{array}$ & $\begin{array}{l}-0.0807 \\
(0.547)\end{array}$ & - & - & $\begin{array}{c}0.728 \\
(94.51)\end{array}$ & $\begin{array}{c}0.446 * * \\
(0.18)\end{array}$ & $\begin{array}{c}7.705 * * * \\
(0.894)\end{array}$ \\
\hline Years dummies & Yes & Yes & Yes & Yes & Yes & Yes & Yes & Yes & Yes & Yes \\
\hline $\begin{array}{c}\text { No. of. } \\
\text { observations }\end{array}$ & 362 & 362 & 362 & 362 & 362 & 362 & 362 & 362 & 362 & 362 \\
\hline No. of. countries & 62 & 62 & 62 & 62 & 62 & 62 & 62 & 62 & 62 & 62 \\
\hline AR (2) & -1.45 & -1.18 & -1.07 & -0.99 & -1.66 & -1.08 & -1.70 & -0.87 & -0.07 & -0.30 \\
\hline AR (2) p-value & 0.146 & 0.237 & 0.287 & 0.322 & 0.097 & 0.282 & 0.089 & 0.384 & 0.946 & 0.766 \\
\hline Hansen Stat & 9.47 & 13.13 & 10.12 & 8.24 & 11.64 & 13.31 & 4.86 & 12.89 & 10.88 & 9.87 \\
\hline Hansen p-value & 0.893 & 0.663 & 0.860 & 0.941 & 0.768 & 0.579 & 0.996 & 0.681 & 0.817 & 0.874 \\
\hline
\end{tabular}

Source: Authors' calculations based on data obtained from the World Bank's data and data constructed from the quality of air, port, railroad and road, availability of latest technologies, business ICT use, mobile telephone subscriptions/100 pop, firm-level technology absorption and individuals using the internet. Robust standard errors in parentheses.

$* * * \mathrm{p}<0.01, * * \mathrm{p}<0.05, * \mathrm{p}<0$.

\subsection{Effects of Soft Infrastructure on Exports}

The regression shown in Table 6 suggests a negative association between the changes in the cost, time, document and exports. A 1 percentage point rise in the cost, time and documentation leads to a decrease in total exports of 0.106, 0.160 and 0.0896, respectively. This result is similar to those obtained by Djankov, Freund and Pham (2010), who found a negative relationship between cost to export and exports. The results presented in Columns 4-8 on the quality of institutions clearly show that poor institutional quality has a negative impact on exports, as many researchers have shown, such as Anderson and Marcoullier (2002); Meon and Sekkat (2006). Our study shows that a 1\% increase in government efficiency increases total exports by 0.345 .

The importance of government efficiency has been widely discussed by Ranjan and Lee (2007); Helble, Shepherd, and Wilson (2009), however, Columns 6-8 indicate that the burden of government regulation, irregular payments and bribes, and the prevalence of trade barriers have a negative relationship with total exports. In the East Asia Pacific, tariffs and procedures for exports are relatively high. Most of the coefficients of soft infrastructure variables are positive, and statistically significantly different from zero at $1 \%$ significance level. We have statistical evidence that all those variables affect exports from East Asia Pacific countries. Furthermore, in Sub-Saharan Africa, except for the coefficient of government efficiency, which is negative and statistically insignificant, all other coefficients are positive and statistically significantly different from zero at the $1 \%$ significance level. 
Table 6. System-GMM estimates of the effect of soft infrastructure on export

\begin{tabular}{|c|c|c|c|c|c|c|c|c|c|c|}
\hline Variables & Model 1 & Model 2 & Model 3 & Model 4 & Model 5 & Model 6 & Model 7 & Model 8 & Model 9 & Model 10 \\
\hline Export (-1) & $\begin{array}{l}0.843 * * * \\
(0.0162)\end{array}$ & $\begin{array}{l}0.853 * * * \\
(0.0152)\end{array}$ & $\begin{array}{l}0.858 * * * \\
(0.00926)\end{array}$ & $\begin{array}{l}0.853 * * * \\
(0.0122)\end{array}$ & $\begin{array}{l}0.884 * * * \\
(0.013)\end{array}$ & $\begin{array}{l}0.852 * * * \\
(0.0108)\end{array}$ & $\begin{array}{l}0.750 * * * \\
(0.0121)\end{array}$ & $\begin{array}{l}0.864 * * * \\
(0.0126)\end{array}$ & $\begin{array}{l}0.849 * * * \\
(0.0126)\end{array}$ & $\begin{array}{l}0.380 * * * \\
(0.0885)\end{array}$ \\
\hline GDP per Capita & $\begin{array}{l}0.104 * * * \\
(0.0241)\end{array}$ & $\begin{array}{l}0.248 * * * \\
(0.024)\end{array}$ & $\begin{array}{l}0.178 * * * \\
(0.0162)\end{array}$ & $\begin{array}{l}0.237 * * * \\
(0.0236)\end{array}$ & $\begin{array}{l}0.112 * * * \\
(0.0203)\end{array}$ & $\begin{array}{l}0.125 * * * \\
(0.0222)\end{array}$ & $\begin{array}{l}0.722 * * * \\
(0.043)\end{array}$ & $\begin{array}{l}0.155 * * * \\
(0.0224)\end{array}$ & $\begin{array}{l}0.238 * * * \\
(0.0215)\end{array}$ & $\begin{array}{l}1.398 * * * \\
(0.264)\end{array}$ \\
\hline $\begin{array}{l}\text { Population } \\
\text { density }\end{array}$ & $\begin{array}{l}0.191 * * * \\
(0.0313)\end{array}$ & $\begin{array}{l}0.231 * * * \\
(0.0288)\end{array}$ & $\begin{array}{l}0.140 * * * \\
(0.0233)\end{array}$ & $\begin{array}{l}0.195 * * * \\
(0.0278)\end{array}$ & $\begin{array}{l}0.100 * * * \\
(0.0226)\end{array}$ & $\begin{array}{l}0.162 * * * \\
(0.0271)\end{array}$ & $\begin{array}{l}0.243 * * * \\
(0.0454)\end{array}$ & $\begin{array}{l}0.136 * * * \\
(0.0256)\end{array}$ & $\begin{array}{l}0.166 * * * \\
(0.0254)\end{array}$ & $\begin{array}{l}0.5 \\
(0.372)\end{array}$ \\
\hline $\begin{array}{l}\text { Cost to export } \\
\text { Time to export }\end{array}$ & $\begin{array}{l}-0.106 * * * \\
(0.00575)\end{array}$ & $\begin{array}{l}-0.160 * * * \\
(0.0088)\end{array}$ & & & & & & & & $\begin{array}{l}0.00332 \\
(0.107) \\
0.381 \\
(0.609)\end{array}$ \\
\hline $\begin{array}{l}\text { Document } \\
\text { export }\end{array}$ & & & $\begin{array}{l}-0.089 * * * \\
(0.0142)\end{array}$ & & & & & & & $\begin{array}{l}0.627 * \\
(0.337)\end{array}$ \\
\hline $\begin{array}{l}\text { Government } \\
\text { efficiency }\end{array}$ & & & & $\begin{array}{l}0.345^{* * *} \\
(0.0506)\end{array}$ & & & & & & $\begin{array}{l}3.512 * * * \\
(0.782)\end{array}$ \\
\hline $\begin{array}{l}\text { Burden } \\
\text { customs } \\
\text { procedures }\end{array}$ & & & & & $\begin{array}{l}-0.00273 \\
(0.017)\end{array}$ & & & & & $\begin{array}{l}0.435 \\
(0.336)\end{array}$ \\
\hline $\begin{array}{l}\text { Burden } \\
\text { government } \\
\text { regulation }\end{array}$ & & & & & & $\begin{array}{l}-0.296 * * * \\
(0.0404)\end{array}$ & & & & $\begin{array}{l}-1.322 * * \\
* \\
(0.44)\end{array}$ \\
\hline $\begin{array}{l}\text { Irregular } \\
\text { Payments and } \\
\text { bribes }\end{array}$ & & & & & & & $\begin{array}{l}-0.449 * * * \\
(0.0336)\end{array}$ & & & $\begin{array}{l}-0.564 * \\
(0.3)\end{array}$ \\
\hline $\begin{array}{l}\text { Prevalence } \\
\text { trade barriers }\end{array}$ & & & & & & & & $\begin{array}{l}-0.121 * * * \\
(0.0306)\end{array}$ & & $\begin{array}{l}0.0792 \\
(0.262)\end{array}$ \\
\hline $\begin{array}{l}\text { Transparency of } \\
\text { government } \\
\text { policymaking }\end{array}$ & & & & & & & & & $\begin{array}{l}-0.328 * * * \\
(0.0324)\end{array}$ & $\begin{array}{l}-2.421 * * \\
* \\
(0.861)\end{array}$ \\
\hline $\begin{array}{l}\text { Sub-Saharan } \\
\text { Africa }\end{array}$ & $\begin{array}{l}-0.074 \\
(0.058)\end{array}$ & $\begin{array}{l}-0.0237 \\
(0.0409)\end{array}$ & $\begin{array}{l}-0.00026 \\
(0.0269)\end{array}$ & $\begin{array}{l}0.403 * * * \\
(0.0374)\end{array}$ & $\begin{array}{l}-0.0156 \\
(0.0372)\end{array}$ & $\begin{array}{l}0.227 * * * \\
(0.03)\end{array}$ & $\begin{array}{l}0.578 * * * \\
(0.0851)\end{array}$ & $\begin{array}{l}0.0761 * * \\
(0.0371)\end{array}$ & $\begin{array}{l}0.236 * * * \\
(0.045)\end{array}$ & $\begin{array}{l}-0.22 \\
(0.38)\end{array}$ \\
\hline East Asia Pacific & $\begin{array}{l}-0.639 * * * \\
(0.123)\end{array}$ & $\begin{array}{l}-0.232 * \\
(0.124)\end{array}$ & $\begin{array}{l}0.494 * * * \\
(0.0851)\end{array}$ & $\begin{array}{l}0.548 * * * \\
(0.0882)\end{array}$ & $\begin{array}{l}0.379 * * * \\
(0.102)\end{array}$ & $\begin{array}{l}0.601 * * * \\
(0.0901)\end{array}$ & $\begin{array}{l}0.846 * * * \\
(0.104)\end{array}$ & $\begin{array}{l}0.427 * * * \\
(0.1)\end{array}$ & $\begin{array}{l}0.486 * * * \\
(0.0892)\end{array}$ & $\begin{array}{l}2.401 \\
(1.663)\end{array}$ \\
\hline Constant & $\begin{array}{l}2.304 \\
(250.9)\end{array}$ & - & $\begin{array}{l}1.466^{* * * *} \\
(0.326)\end{array}$ & $\begin{array}{l}0.417 \\
(255.7)\end{array}$ & $\begin{array}{l}1.476^{* * * *} \\
(0.329)\end{array}$ & $\begin{array}{l}1.596 * * * \\
(0.335)\end{array}$ & - & - & - & $\begin{array}{l}2.468 \\
(3.666)\end{array}$ \\
\hline Years dummies & Yes & Yes & Yes & Yes & Yes & Yes & Yes & Yes & Yes & Yes \\
\hline $\begin{array}{l}\text { No. } \\
\text { observations }\end{array}$ & 311 & 311 & 311 & 311 & 311 & 311 & 311 & 311 & 311 & 311 \\
\hline No. of. countries & 54 & 54 & 54 & 54 & 54 & 54 & 54 & 54 & 54 & 54 \\
\hline $\mathrm{AR}(2)$ & -1.13 & -0.99 & -0.99 & -1.48 & -0.44 & 1.90 & -0.98 & -0.72 & -1.08 & -1.27 \\
\hline AR (2) p-value & 0.258 & 0.323 & 0.321 & 0.140 & 0.656 & 0.058 & 0.328 & 0.471 & 0.282 & 0.204 \\
\hline Hansen Stat & 11.01 & 10.65 & 11.45 & 10.94 & 11.55 & 14.38 & 12.27 & 12.64 & 13.31 & 10.51 \\
\hline Hansen p-value & 0.752 & 0.777 & 0.720 & 0.757 & 0.713 & 0.497 & 0.659 & 0.630 & 0.579 & 0.787 \\
\hline
\end{tabular}

Source: Authors' calculations based on data obtained from the World Bank's data and data constructed from cost to export, time to export, document to export, government efficiency, burden of customs procedures, burden of government regulation, irregular payments and bribes, prevalence of trade barriers and transparency of government policymaking. Robust standard errors in parentheses.

$* * * \mathrm{p}<0.01, * * \mathrm{p}<0.05, * \mathrm{p}<0.1$ 


\section{Conclusion}

This study aimed to analyse all aspects of trade facilitation, including hard and soft infrastructure and their impacts on international trade. We constructed 18 variables from the primary data, and then we grouped them into four trade facilitation measures. The data was collected in 33 lower-middle-income and 30 upper-middle-income countries over the period 2011-2017.

The results suggest that improving physical infrastructure leads to an increase in exports more than any other trade facilitation measure. ICT and institutions also play an important role in exports, although not in the expected sense. On the other hand, their improvements remain an excellent advantage for trade. Quality of air, ports, railroads, and roads was used as a proxy for physical infrastructure. The estimation result is positive and significant for the quality of ports and roads. For ICT, the availability of the latest technologies, business ICT use, mobile telephone subscriptions/100 pop, firm-level technology absorption, and individuals using the internet were found to be negative and significant. For soft infrastructure, this study identifies trade barriers and also government inefficiency as the main obstacles to export. Our estimates show that the reduction in cost, time, and document procedure leads to increased exports. Thus, the main objective of trade facilitation would be to reduce all sorts of export-related costs.

Lower-middle-income countries, as most Sub-Saharan Africa countries, suffer enormously from the lack of infrastructure and advanced technology. In addition, weak governance and institutions are an economic risk factor and are linked to many other risk factors such as poverty and inequality and planned urban development. On the other hand, Asia Pacific countries have made enormous progress in the development of infrastructure and technology. In recent years, they have also increased administrative procedures and tariffs to protect themselves against competition and to encourage local industry.

Finally, the results obtained as a whole, allow us to conclude that both hard and soft infrastructure must be considered at the same level, as the effectiveness of exports depends on both. This study offers an excellent opportunity to exchange views and share knowledge on factors aimed at improving national competitiveness, as well as international trade. We all have much to share and learn about multi-sectoral partnerships and engagement, given that the benefit of trade facilitation is for both importing and exporting countries. We are convinced that the potential for technology transfer in the world is enormous. It can help underdeveloped countries to improve their productivity, and to be more efficient in trade. The most significant effort to be made, however, remains at the institutional level.

\section{Acknowledgements}

This research was financially supported by the National Social Science Fund (Grant No.: 18BJY168): The research on logistics development of Gwadar port under the background of the "Belt and Road" and China-Pakistan economic corridor.

\section{References}

Anderson, J. E., \& Marcouiller, D. (2002). Insecurity and the pattern of trade: An empirical investigation. Review of Economics and Statistics, 84(2), 342-352.

Arellano, M., \& Bond, S. (1991). Some tests of specification for panel data: Monte Carlo evidence and an application to employment equations. The Review of Economic Studies, 58(2), 277-297.

Arellano, M., \& Bover, O. (1995). Another look at the instrumental variable estimation of error-components models. Journal of Econometrics, 68(1), 29-51.

Blundell, R., \& Bond, S. (1998). Initial conditions and moment restrictions in dynamic panel data models. Journal of Econometrics, 87(1), 115-143.

Blundell, R., Bond, S., \& Windmeijer, F. (2001). Estimation in dynamic panel data models: improving on the performance of the standard GMM estimator. Nonstationary Panels, Panel Cointegration, and Dynamic Panels.

Bun, M. J., \& Windmeijer, F. (2010). The weak instrument problem of the system GMM estimator in dynamic panel data models. The Econometrics Journal, 13(1), 95-126.

Clark, X., Dollar, D., \& Micco, A. (2004). Port efficiency, maritime transport costs, and bilateral trade. Journal of Development Economics, 75(2), 417-450.

Collier, P. G., \& Gunning, J. J. W. (1997). Explaining African Economic Performance. Journal of Economic Literature, 37 .

Cooperation, A. P. E. (1999). Assessing APEC trade liberalization and facilitation: 1999 update. Report by the Economic Committee, September (Singapore: APEC Secretariat). 
Djankov, S., Freund, C., \& Pham, C. S. (2010, February). Trading on Time'. The Review of Economics and Statistics, 92.

Do, Q. T., \& Levchenko, A. A. (2006). Trade, inequality, and the political economy of institutions. The World Bank.

Eifert, B., Gelb, A., \& Ramachandran, V. (2005). Business environment and comparative advantage in Africa: Evidence from the investment climate data. Banque Mondiale, Washington: DC, 195-233.

Elbadawi, I., Mengistae, T., \& Zeufack, A. (2006). Market access, supplier access, and Africa's manufactured exports: A firm level analysis. J. Int. Trade \& Economic Development, 15(4), 493-523.

Fink, C., Mattoo, A., \& Neagu, I. (2002). Assessing the impact of communication costs on international trade. The World Bank.

Fink, C., Mattoo, A., \& Neagu, I. C. (2002). Trade in international maritime services: how much does policy matter?. The World Bank Economic Review, 16(1), 81-108.

French, S. (2016). The composition of trade flows and the aggregate effects of trade barriers. Journal of International Economics, 98, 114-137.

Freund, C. L., \& Weinhold, D. (2000). An empirical investigation of the Internet and international trade: The case of Bolivia (No. 05/00). Documento de Trabajo.

Hair, J. F., Black, W. C., Babin, B. J., Anderson, R. E., \& Tatham, R. L. (1998). Multivariate Data Analysis (Vol. 5, No. 3, pp. 207-219). Upper Saddle River, NJ: Prentice hall.

Helble, M., Shepherd, B., \& Wilson, J. S. (2009). Transparency and regional integration in the Asia Pacific. World Economy, 32(3), 479-508.

Hertel, T. W., Walmsley, T., \& Itakura, K. (2001). Dynamic effects of the" new age" free trade agreement between Japan and Singapore. Journal of Economic Integration, 446-484.

Hummels, D. (2001). Time as a trade barrier Purdue University Press. West Lafayette.

Ismail, N. W., \& Mahyideen, J. M. (2015). The Impact of infrastructure on trade and economic growth in selected economies in Asia.

Iwanow, T., \& Kirkpatrick, C. (2009). Trade facilitation and manufactured exports: Is Africa different? World Development, 37(6), 1039-1050.

Jordaan, A. C. (2014). The impact of trade facilitation factors on South Africa's exports to a selection of African countries. Development Southern Africa, 31(4), 591-605.

Jouanjean, M. A., Gachassin, M., \& te Velde, D. W. (2016). Regional infrastructure for trade facilitation-impact on growth and poverty reduction. ODI, London.

Kovak, B. K. (2013). Regional effects of trade reform: What is the correct measure of liberalization?. American Economic Review, 103(5), 1960-76.

Li, Y., \& Wilson, J. S. (2009). Trade facilitation and expanding the benefits of trade: Evidence from firm level data (No. 71). ARTNet Working Paper Series.

Meon, P. G., \& Sekkat, K. (2006). Institutional quality and trade: Which institutions. Which Trade, 06-06.

Minor, P., \& Tsigas, M. (2008). Impacts of better trade facilitation in developing countries: analysis with a new GTAP database for the value of time in trade.

Moïsé, E., \& Sorescu, S. (2013). Trade facilitation indicators.

Morrison, T. K. (1977). The effects of population size and population density on the manufactured exports of developing countries. Southern Economic Journal, 1368-1371.

Portugal-Perez, A., \& Wilson, J. S. (2012). Export performance and trade facilitation reform: Hard and soft infrastructure. World Development, 40(7), 1295-1307.

Ranjan, P., \& Lee, J. Y. (2007). Contract enforcement and international trade. Economics \& Politics, 19(2), 191-218.

Sakyi, D., Bonuedi, I., \& Opoku, E. E. O. (2018). Trade facilitation and social welfare in Africa. Journal of African Trade, 5(1-2), 35-53.

Shepherd, B. (2016). Infrastructure, trade facilitation, and network connectivity in Sub-Saharan Africa. Journal of African Trade, 3(1-2), 1-22. 
Shepherd, B., \& Wilson, J. S. (2008). Trade facilitation in ASEAN member countries: Measuring progress and assessing priorities. The World Bank.

United Nations conference on trade and development. (2001). Trade and development report. New York and Geneva.

Werts, C. E., Linn, R. L., \& Jöreskog, K. G. (1974). Intraclass reliability estimates: Testing structural assumptions. Educational and Psychological Measurement, 34(1), 25-33.

Wilson, J. S., Mann, C. L., \& Otsuki, T. (2003). Trade facilitation and economic development: A new approach to quantifying the impact. The World Bank Economic Review, 17(3), 367-389.

Wilson, J. S., Mann, C. L., \& Otsuki, T. (2005). Assessing the benefits of trade facilitation: A global perspective. World Economy, 28(6), 841-871.

Wilson, J. S., Mann, C., Woo, Y. P., Assanie, N., \& Choi, I. (2002). Trade facilitation: A development perspective in the Asia Pacific Region. APEC Committee on Trade and Investment.

\section{Copyrights}

Copyright for this article is retained by the author(s), with first publication rights granted to the journal.

This is an open-access article distributed under the terms and conditions of the Creative Commons Attribution license (http://creativecommons.org/licenses/by/4.0/). 